\section{Family Burden of Schizophrenia in Pasung During COVID- 9 Pandemic: A Scoping Review}

Indonesian Nursing Journal of Education and Clinic (INJEC)

$185-196$

Volume 5, Issue 2, December 2020

DOI: 10.24990/injec.v5i2.315

injec.aipni-ainec.org/index.php/INJEC/index

Received : 2020-07-23

Accepted : 2020-08-15

The Association of Indonesian Nurse

Education Center (AINEC)

\author{
Shofi Khaqul Ilmy' ${ }^{\mathbb{D}}$, Noorhamdani Noorhamdani' ${ }^{1}$, Heni Dwi Windarwati'
}

\begin{abstract}
Introduction: The long-term care in schizophrenia patients can cause care burdens, which will relate to the family's decision to do pasung. The perceived burden will be even heavier because of the COVID-19 pandemic. This review aims to identify the family care burden affecting pasung in schizophrenic patients during the COVID-19 pandemic.

Methods: This scoping review was conducted by searching four databases, namely ProQuest, Science Direct, and EBSCO, and Google Scholar in the past ten years. This study uses the PRISMA 2009 protocol in filtering articles from the database. Researchers summarize based on the significance value for quantitative research, based on themes' qualitative research, and discussed factors mentioned which may influence the family. Thus, we obtained 15 articles for final review.

Results: The results obtained that the subjective burden felt by the family is a feeling of worry and sadness due to the patient's aggressive behavior and the safety of the patient, family, and environment. The objective burdens most felt by families are financial burdens, both medical costs, transportation to reach mental health services, and the cost of daily living. The COVID-19 pandemic will affect both types of care burdens, thereby affecting the quality of care for families with schizophrenia patients in pasung.

Conclusion: Schizophrenia patients are one of the populations that are vulnerable to COVID-19. Nurse plays a role in the ability to overcome the burden of schizophrenia care and improve adaptation to the current pandemic to create optimal mental health in the community.
\end{abstract}

\title{
Keywords
}

care burden; COVID-19; mental health; schizophrenia family; scoping review

\section{INTRODUCTION}

The World Health Organization (WHO) established Corona Virus Disease in 2019 (COVID-19) as a Public Health Emergency of International Concern (PHEIC), which has been troubling throughout the world (Keliat et al., 2020). Global media, national and international organizations, epidemiologists, and health workers have constantly released the latest information and recommendations regarding the transmission and management of COVID-19 (Torales, O'Higgins, CastaldelliMaia, \& Ventriglio, 2020). On I July, 2020, COVID-19 had spread in 216 countries, as

\footnotetext{
I School of Nursing, Faculty of Medicine, Universitas Brawijaya, Malang - Indonesia

Corresponding Author:

Heni Dwi Windarwati, School of Nursing, Faculty of Medicine, Universitas Brawijaya, Malang - Indonesia

Veteran street, Malang, East Java, Indonesia Post code: 64I45, Fax: (034I) 564755

Email: henipsik.fk@ub.ac.id
} 
many as $10,357,662$ people confirmed positive and 508,055 deaths due to COVID-19. The Indonesian government has announced as many as 57,770 positive confirmed cases of COVID-19, 25,595 cases of recovery, and 2,934 cases died of COVID- 19 (Gugus Tugas Percepatan Penanganan COVID-19, 2020). Various psychosocial impacts are felt by the community regarding the development of the COVID-19 outbreak, including fears of transmission, death, loss of work, feeling helpless, stigma, separation from family due to quarantine, boredom, depression, and the fear of going to a health facility (WHO, 2020). The impact will be felt by all groups of people, especially by families with schizophrenia patients.

Schizophrenia patients are a vulnerable group due to the COVID-19 pandemic (Keliat et al., 2020). Schizophrenia is a severe and chronic mental disorder which has affected more than 21 million people worldwide and is more prevalent in men, with an estimated prevalence of $0.5-1 \%$ worldwide (Andreasen \& Black, 2006). Schizophrenia is multifactorial, which occurs due to the interaction of genetic, psychological, and environmental factors. Most schizophrenia patients throughout the world live in low to middle income countries, where access to health services is limited to access. Schizophrenia is at high risk of getting stigma, discrimination, and also human rights violations from the community (WHO, 20I8). This causes the majority of schizophrenia patients to depend on care and family support to meet their treatment or daily needs, related to long-term treatment and care.

The family plays a significant role in the recovery of schizophrenia patients by maintaining life stability and preventing relapse of illness every day (Amagai, Takahashi, \& Amagai, 2016). Families will experience anxiety and depressive symptoms, low self-esteem, and tend to use maladaptive coping strategies (Greene, Cohen, Siskowski, \& Toyinbo, 2017; Madathumkovilakath,

Kizhakkeppattu,
Thekekunnath, \& Kazhungil, 2018). In many cases, families are often overwhelmed in treating schizophrenia patients, such as meeting the daily basic needs of the whole family, medical treatment regimens (including drugs and controls), and monitoring the activities of schizophrenia patients every day. Family burdens are becoming recognized as a relevant concept in schizophrenia because they can have adverse long-term effects (Mantovani et al., 2016). The limitations of family knowledge about schizophrenia, the emergence of a COVID-19 pandemic, low economic factors, and environmental factors will cause families to choose to do 'pasung', either with physical restraint or confinement.

Pasung of people with severe mental disorders is one of the mental health problems in developing countries, including in Indonesia (Firdaus, 2016). Pasung is defined as an act of isolation and restriction of movement (physically) of a person with mental disorder by the family, and carried out to control the patient's destructive behavior. Apart from using wood or chains on the feet, pasung also involves confinement and neglect (Laila, Mahkota, Shivalli, Bantas, \& Krianto, 2019). Pasung is usually done in anything from over a few days to years (Hartini, Fardana, Ariana, \& Wardana, 2018). About $90 \%$ of cases of pasung are performed in schizophrenia patients who are accompanied by aggressive behavior and hallucinations that risk in injuring themselves, others, and damaging the surrounding environment (Daulima, Rasmawati, \& Wardani, 2019; Menteri Kesehatan Republik Indonesia, 2017).

Based on the phenomena, the purpose of this review is to identify the family care burden affecting pasung in schizophrenic patients during the COVID-19 pandemic. Based on conditions before the pandemic, different levels of burden can be found in all families caring for schizophrenia patients, which are influenced by the patient's condition, family, and environmental support. The concept of family burden consists of two different but complementary types, the objective burden refers to the observable consequences of care, and subjective burden refers to the emotional burden of care. 


\section{MATERIALS AND METHODS}

\section{Database search process}

This review was prepared to identify the impact of the COVID-19 pandemic on the family burden on schizophrenia patients in pasung based on previous studies. Because the COVID-19 pandemic is a new issue, we will discuss the effects of COVID-19 after identifying the burden of the family with schizophrenia patients in pasung with a systematic search. We use four databases in conducting a systematic search for the burden of care, including ProQuest, Science Direct, EBSCO, and Google Scholar. The search was performed using the keywords 'family burden', 'schizophrenia', 'pasung', 'physical restraint', 'seclusion', and 'confinement'. The keyword combinations will be shown in Table I.

\section{Search analysis and criteria}

This review uses the Preferred Reporting Item for Systematic Review and Meta-Analysis (PRISMA) 2009 approach to obtain articles in the database. We determined the inclusion and exclusion criteria used in filtering literature search results. Researchers summarize based on the significance value for quantitative research, based on themes' qualitative research, and discussed factors mentioned which may influence the family. Inclusion criteria used in this review include: I) The study subjects were schizophrenia patients and their families; 2) Do pasung on schizophrenia patients; 3) Research is carried out in developing countries, based on the list of developing countries in the economic sector listed in World Economic Situation and Prospects 2019 by the United Nation; and 4) Articles published in Indonesian journals, at least indexed by SINTA (Science and Technology Index for journal in Indonesia) at grade 2. Exclusion criteria used include I) Traditional literature review articles; 2) Only in the form of abstracts and other forms of writing (poster presentation, award, or oral presentation). The quality of research articles was assessed using JBI Critical Appraisal Tools with a minimum criterion of $60 \%$ by two authors.

\section{Article selection and data extraction}

The search for articles on the database based on the PRISMA 2009 protocol is depicted in Figure I, and then obtained 15 articles that were carried out with data extraction. The relevant article will be summarized in Table 2.

Table I. Keyword combinations specified in the database search

\begin{tabular}{cllc}
\hline No. & \multicolumn{1}{c}{ Database } & \multicolumn{1}{c}{ Keyword combination } & Result \\
\hline 1. & ProQuest & $\begin{array}{l}\text { "family burden" AND "schizophrenia" AND "pasung" OR } \\
\text { "physical restraint" OR "seclusion" OR "confinement" }\end{array}$ & 3,485 \\
2. & Science Direct & $\begin{array}{l}\text { "family burden" AND "schizophrenia" AND "pasung" OR } \\
\text { "physical restraint" OR "seclusion" OR "confinement" }\end{array}$ & 5,942 \\
3. & EBSCO & $\begin{array}{l}\text { "family burden" AND "schizophrenia" AND "pasung" OR } \\
\text { "physical restraint" OR "seclusion" OR "confinement" }\end{array}$ & 1,784 \\
4. & Google Scholar & $\begin{array}{l}\text { "family burden" AND "schizophrenia" AND "pasung" OR } \\
\text { "physical restraint" OR "seclusion" OR "confinement" }\end{array}$ & 8,850 \\
\hline
\end{tabular}




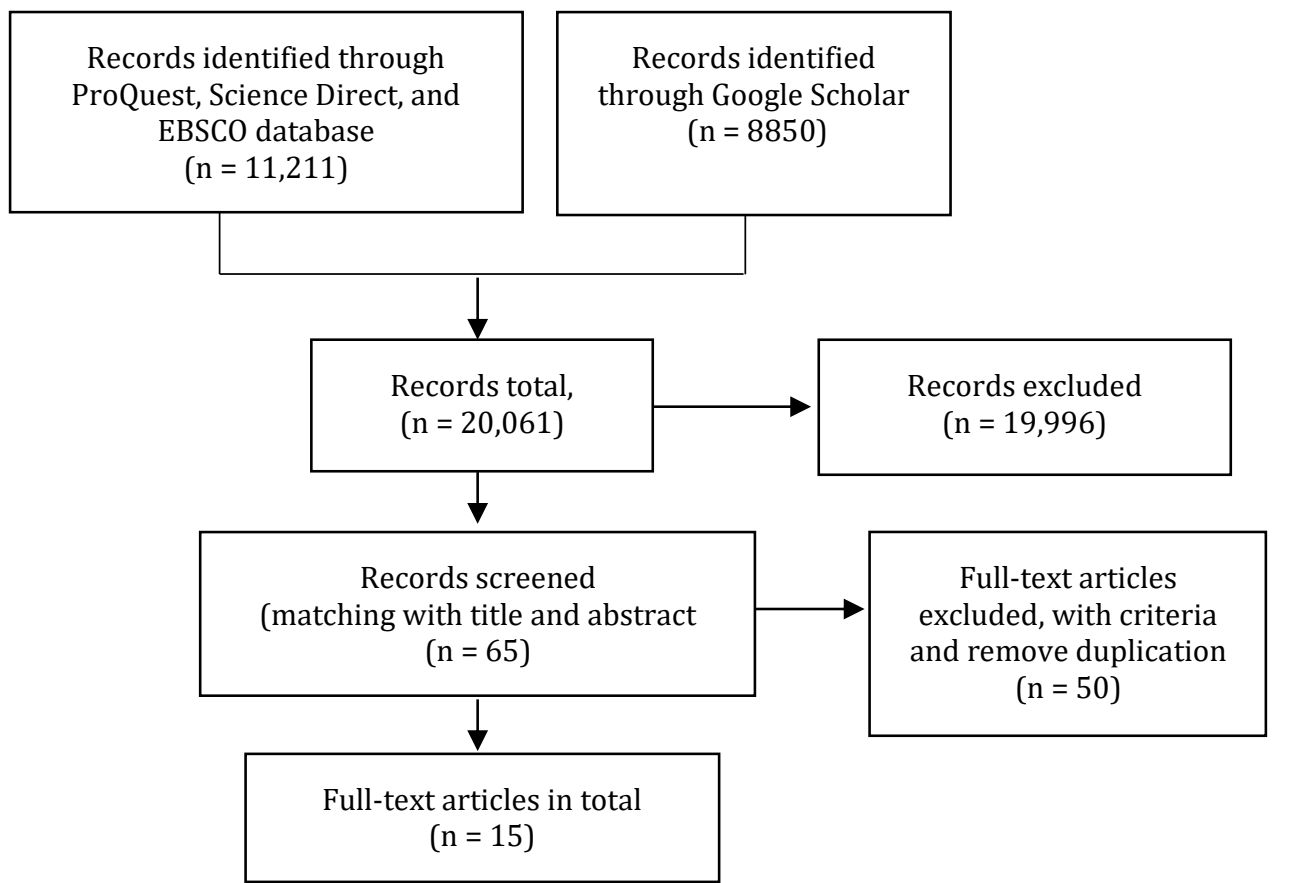

\section{RESULTS}

Based on Table I, preliminary search results obtained 3,485 articles from ProQuest, 5,942 articles from Science Direct, I,784 articles from EBSCO, and 8,850 articles from Google Scholar. Based on the review of the title and abstract, 13 articles from ProQuest were obtained, 16 articles from Science Direct, 9 articles from EBSCO, and 27 articles from Google Scholar. Of the 65 articles, each was read in full or in full text. Fifty articles did not fit the researchers' inclusion criteria, so were excluded. Then, there were 15 articles for further review.

Based on Table 2, it was found that $86.7 \%$ of studies were conducted in Indonesia, and 13.3\% were conducted in Ethiopia and Nepal, which are developing countries. The study was conducted on people with severe mental disorders in the age range of 16-68 years, and most were male. The length of pasung was found to vary, ranging from one day to 24 years. In caregivers' families, patients are aged 14-80 years, and most are male. Overall, research subjects have a low level of education and economic level.

On the subjective burden of family care, the majority of families with schizophrenia patients with pasung feel negative feelings. Worries occur due to schizophrenia patients wandering and doing violence to themselves (the risk of suicide), families, and the surrounding environment, both physically and verbally (Hall et al., 2019; Laila, Mahkota, Krianto, \& Shivalli, 2018; Laila et al., 2019; Nihayati, Mukhalladah, \& Krisnana, 2016; Puteh, Marthoenis, \& Minas, 20II; Subu, Holmes, \& Elliot, 2016; Yusuf, Tristiana, \& Purwo, 2017). Feelings of pity and fear by the family are also related to the risk of violence to schizophrenia patients by other people (Asher et al., 2017; Buanasari, Daulima, \& Wardani, 2018; Hall et al., 2019; Subu et al., 2016) and also the risk of sexual violence (Asher et al., 2017). Based on that risk, the family tries to protect schizophrenia patients by doing pasung (Asher et al., 2017; Laila et al., 2018). The burden felt by the family is also influenced by stigma (Astuti, 2017; Nurhayati, Widjanarko, \& Nugraheni, 2020), and the assumption that pasung is considered as an action that is usually applied to schizophrenia patients in the community (Astuti, 2017; Laila et al., 2018). The decision to pasung is based on consideration of meeting the needs of patients (routine treatment and daily activities), family (management of care burden), and community safety.

Burn-out in caring is also felt by families every day (Nihayati et al., 2016; Yunita, Yusuf, Nihayati, \& Hilfida, 2019). Burn-out is felt aggravated by feelings of helplessness (Asher et al., 2017; Nihayati et al., 2016; Yunita et al., 2019), no support (Asher et al., 2017), and a long-term treatment process (Dewi, Daulima, \& Wardani, 2019; Nurhayati et al., 2020). 
Families with pasung cases continue to feel responsible for meeting the basic daily needs of schizophrenia patients (Buanasari et al., 2018; Hall et al., 2019) and still have hope for their recovery (Yusuf et al., 2017).

Concerning the burden of objective family care, financial burdens and damage due to violent behavior are burdens experienced in the family, which led to the decision to pasung (Dewi et al., 20/9). The financial burden experienced is because the family cannot meet the medical expenses (Laila et al., 2018; Yunita et al., 2019), and the cost of the daily needs of schizophrenia patients (Laila et al., 2018). Some cases in Indonesia found that some families get health insurance in the treatment of schizophrenia patients (Laila et al., 2019), but still feel the financial burden of needs outside of treatment. The burden is made worse by patients who cannot fulfill their daily basic needs independently (Yusuf et al., 20I7), families who cannot work because they have to accompany patients every day, low economic rates, and low knowledge about patient care (Astuti, 2017; Dewi et al., 2019; Laila et al., 2018; Nurhayati et al., 2020; Shrestha, 2018; Yusuf et al., 2017). The family chooses to do pasung because the family considers it to be cheaper (by gathering wood and iron materials around the house to make a cage) (Yusuf et al., 2017), so they can do pasung to ensure patient safety and can even provide drugs (oral or injection) more easily (Asher et al., 2017).

Another objective burden is limited access and availability of mental health services (Laila et al., 20 I8). The distance that must be traveled and the cost of transportation in medical treatment becomes a family barrier factor in bringing schizophrenia patients to health workers (Laila et al., 2018; Nurhayati et al., 2020). In some cases of pasung, families choose to provide alternative medicine, shamans, or religious leaders (Puteh et al., 20II; Yunita et al., 2019), because they feel lost faith in medical treatment (Puteh et al., 20II) and these alternative actions cost less.

\section{DISCUSSIONS}

COVID-19 pandemic causes anxiety and depression that is widespread throughout the world. Not only physical problems, but mental health problems that also arise due to lockdown during COVID-19 pandemic. The impact on psychological wellbeing is experienced by all populations, from individuals to society, both to healthy people and vulnerable groups (Bhat et al., 2020; Holmes et al., 2020). The impact on mental health can be explained with the assumption that people are more focused on their physical health (now and future), because COVID-19 has obvious physical health impacts, from mild to death. However, greater mental health effects might be discovered after the pandemic (Repišti et al., 2020). We believe that this impact will have a greater impact on vulnerable groups than healthy people because it has heavier risk factors, with no exception in schizophrenia patients and their families.

Schizophrenia is related to a decrease in the function of fulfilling daily needs and social functions and is even considered harmful to oneself, family, or even the environment. Families, as primary caregivers, are often overwhelmed by the uncontrolled behavior of schizophrenia patients (Mantovani et al., 2016). Research conducted by Sharma et al. (2017) stated that $72 \%$ of families had high-stress levels, 25\% had depression, and 29\% had anxiety related to the treatment of schizophrenia patients. Some of the effects of the burden of care include mental health problems (e.g., depression, anxiety, stress, and fatigue), decreased physical health (e.g. increased blood pressure and risk of diabetes), and other negative effects (e.g. family dysfunction, social isolation, excessive use of health services, and financial problems) (Souza et al., 2017). The burden of schizophrenia care will be borne by the family, where it is not available in mental health services (Arun, Inbakamal, Tharyan, \& Premkumar, 2018). During the COVID-19 pandemic, information about COVID-19 can worsen delusions, hallucinations, and irregular thinking that are usually experienced by schizophrenia patients (Hamada \& Fan, 2020). On the other hand, physical distancing protocols aimed at reducing the spread of disease can increase the risk of loneliness and social isolation in this population. Based on these impacts, psychological symptoms that arise during this pandemic must be identified and managed in developing treatment plans during COVID-19, while implementing physical distancing protocols in the community (Druss, 2020). 
The subjective burden felt by families with schizophrenia focuses on negative emotions arising from treatment. Feelings of sadness, worry, hopelessness, and helplessness are feelings that are often felt. Families are required to be able to adapt to changes in the patient's aggressive behavior and keep trying to protect patients from danger. Providing schizophrenia care and supervision, together with meeting other daily routine needs, puts families at risk of feeling high levels of stress (Venkatesh, Andrews, Parsekar, Singh, \& Menon, 2015). Negative feelings that are felt will be aggravated by the stigma that comes from other people. The patient or family personally feel how the community sees and treats the patient and their family (Huang, Jen, \& Lien, 2016). Patients and families may even face a double stigma associated with coronavirus infection and their mental health conditions. Worries perceived by the family could both exacerbate and be exacerbated by existing anxiety and depressive symptoms (Druss, 2020).

The financial burden is an objective burden that is felt by the majority of families and is felt the biggest and main burden of the families of mental health patients (Koujalgi \& Patil, 20/3). Research conducted by Yu et al. (2017) also found that $76 \%$ of families felt a financial burden (Yu et al., 2017). Although some families can overcome perceived subjective burdens, financial burdens cannot be overcome. Long-term schizophrenia treatment will add to the need for routine medical expenses and basic daily needs, which can increase the prolonged objective burden on the family (Dewi et al., 20/9). The cost of mental health services, transportation to access distant mental health services, patient over-eating behavior, the need to supervise patients more than work, compensation for damage caused by the patient's violent behavior and low economic levels are the main factors toward the financial burden felt by the family. Physical distancing protocols can make patients experience significant emotional distress, and recurrence of psychotic symptoms, which results in an increased risk of hospitalization that can add to the family's financial burden (Hamada \& Fan, 2020). In the current COVID-19 pandemic, we think that the global economic downturn will affect the income of family members, the risk of unilaterally terminating work, and falling income can be a risk factor for families in meeting the needs of the whole family. Also, material support (either from government or community) will affect the family's financial burden on this pandemic.

The role of Community Mental Health Nursing $(\mathrm{CMHN})$ is important in overcoming family burdens in treating schizophrenia patients during the COVID-19 pandemic, with a focus on pasung prevention. This activity must be synergized by the government, health workers, community leaders, and individuals. Early detection, care, counseling, and monitoring by mental health nurses will be able to manage the psychosocial impact of the COVID-19 pandemic, to increase physical immunity and mental immunity. Family-based nursing therapy can help families to provide optimal care for patients, for example, Family Psychoeducation (FPE). This therapy can ease the burden of care felt by the family. Effective therapeutic results will be achieved if there is an integrated mental health service with support from the surrounding environment.

The results obtained from this review have limitations; the articles collected are the literature obtained before the existence of the COVID- 19 pandemic. No recent literature was found regarding the burden of families with schizophrenia patients at the time of the pandemic. This led us to discuss the impact of COVID-19 after identifying the family burden. This has an impact on the possible bias that arises due to the non-actual results of research found. We consider that the burden of care by families with schizophrenia patients will be heavier than before the pandemic.

\section{CONCLUSION}

Individuals with schizophrenia are one of the populations that are vulnerable to COVID19 in the community. Pasung in schizophrenia patients is multifactorial, both from family internal or community members, and can be influenced by the COVID-19 pandemic (related to psychosocial effects on the family). This review emphasizes various family burdens on schizophrenia patients in pasung. It is very important to improve access and quality of mental health services, both by the government and the private sector (especially in rural areas) to realize optimal mental health 
Table 2. Summary of articles on systematic search results

\begin{tabular}{|c|c|c|c|c|c|c|c|c|c|}
\hline \multirow{2}{*}{\multicolumn{2}{|c|}{ Author (Year) }} & \multirow{2}{*}{$\begin{array}{l}\text { JBI } \\
\text { Lvl. }\end{array}$} & \multirow{2}{*}{ Country } & \multirow{2}{*}{ Objective } & \multirow{2}{*}{ Method } & \multirow{2}{*}{ Subject } & \multirow{2}{*}{$\begin{array}{l}\text { Duration } \\
\text { of } \\
\text { Pasung }\end{array}$} & \multicolumn{2}{|c|}{ Burden } \\
\hline & & & & & & & & Subjective & Objective \\
\hline \multicolumn{10}{|c|}{ Evidence of Effectiveness } \\
\hline 1 & $\begin{array}{l}\text { Puteh et al. } \\
\text { (2011) }\end{array}$ & $4 b$ & Indonesia & $\begin{array}{l}\text { To shows the initial } \\
\text { demographic } \\
\text { characteristics and } \\
\text { clinical condition of } \\
\text { patients who have been } \\
\text { treated at the Mental } \\
\text { Hospital }\end{array}$ & Descriptive study & $\begin{array}{l}55 \text { patients post- } \\
\text { pasung }\end{array}$ & $\begin{array}{l}\text { A few } \\
\text { days - } 20 \\
\text { years }\end{array}$ & - & Violent behavior \\
\hline 2. & $\begin{array}{l}\text { Laila et al. } \\
\text { (2019) }\end{array}$ & $3 d$ & Indonesia & $\begin{array}{l}\text { To determine factors } \\
\text { associated with pasung } \\
\text { among patients with } \\
\text { schizophrenia }\end{array}$ & Case-control study & $\begin{array}{l}250 \text { families } \\
\text { members with } \\
\text { schizophrenia } \\
\text { patients (divided } \\
\text { into case and } \\
\text { control group) }\end{array}$ & $\begin{array}{l}1 \text { day - } 12 \\
\text { years }\end{array}$ & - & Violent behavior \\
\hline 3. & $\begin{array}{l}\text { Dewi et al. } \\
\text { (2019) }\end{array}$ & $2 \mathrm{~d}$ & Indonesia & $\begin{array}{l}\text { To know the effect of } \\
\text { family psychoeducation } \\
\text { therapy (FPE) and Care } \\
\text { Decisions Without } \\
\text { Pasung (CDWP) in } \\
\text { families of mental } \\
\text { patients }\end{array}$ & $\begin{array}{l}\text { Quasi } \\
\text { experimental } \\
\text { pretest-posttest } \\
\text { design with a } \\
\text { control group }\end{array}$ & $\begin{array}{l}72 \text { families are } \\
\text { divided into two } \\
\text { groups }\end{array}$ & $\mathrm{n} / \mathrm{a}$ & - & Financial issues \\
\hline 4. & $\begin{array}{l}\text { Shrestha } \\
\text { (2018) }\end{array}$ & $4 b$ & Nepal & $\begin{array}{l}\text { To explore the } \\
\text { knowledge and } \\
\text { attitudes of family } \\
\text { members of mentally ill } \\
\text { patients }\end{array}$ & $\begin{array}{l}\text { Cross-sectional } \\
\text { study }\end{array}$ & $\begin{array}{l}\text { Family member } \\
\text { of severe mental } \\
\text { disorder patient } \\
\text { at } \\
\text { psychiatric } \\
\text { hospital }\end{array}$ & $\mathrm{n} / \mathrm{a}$ & Feel ashamed & $\begin{array}{l}\text { Violent behavior, Lack } \\
\text { knowledge about } \\
\text { pasung. }\end{array}$ \\
\hline 5. & $\begin{array}{l}\text { Nurhayati } \\
\text { et al. } \\
(2020)\end{array}$ & $4 b$ & Indonesia & $\begin{array}{l}\text { To analyze the } \\
\text { determinants factor that } \\
\text { influence pasung in } \\
\text { severe mental illness } \\
\text { patients }\end{array}$ & $\begin{array}{l}\text { Cross sectional } \\
\text { study }\end{array}$ & $\begin{array}{l}2579 \text { families } \\
\text { members with } \\
\text { severe mental } \\
\text { illness patients }\end{array}$ & $\mathrm{n} / \mathrm{a}$ & $\begin{array}{l}\text { Stigma, and family } \\
\text { feel fatigue related to } \\
\text { long-term care. }\end{array}$ & $\begin{array}{l}\text { Lack of knowledge } \\
\text { (mental illness and } \\
\text { pasung), difficult to } \\
\text { access health services } \\
\text { (related to distance and } \\
\text { time), and financial } \\
\text { issues }\end{array}$ \\
\hline
\end{tabular}


Table 2. Summary of articles on systematic search results

\begin{tabular}{|c|c|c|c|c|c|c|c|c|c|}
\hline \multirow{2}{*}{\multicolumn{2}{|c|}{ Author (Year) }} & \multirow{2}{*}{$\begin{array}{l}\text { JBI } \\
\text { Lvl. }\end{array}$} & \multirow{2}{*}{ Country } & \multirow{2}{*}{ Objective } & \multirow{2}{*}{ Method } & \multirow{2}{*}{ Subject } & \multirow{2}{*}{$\begin{array}{l}\text { Duration } \\
\text { of } \\
\text { Pasung }\end{array}$} & \multicolumn{2}{|c|}{ Burden } \\
\hline & & & & & & & & Subjective & Objective \\
\hline \multicolumn{10}{|c|}{ Evidence of Effectiveness } \\
\hline 6. & $\begin{array}{l}\text { Nihayati } \\
\text { et al. } \\
(2016)\end{array}$ & 3 & Indonesia & $\begin{array}{l}\text { To explore family } \\
\text { experience of caring for } \\
\text { severe mental illness } \\
\text { patients post-pasung }\end{array}$ & $\begin{array}{l}\text { Phenomenological } \\
\text { study }\end{array}$ & $\begin{array}{l}6 \text { families (female, } \\
\text { ages of } 48-80 \\
\text { years old) }\end{array}$ & $\mathrm{n} / \mathrm{a}$ & $\begin{array}{l}\text { Families worried } \\
\text { because patients can } \\
\text { still injure themselves }\end{array}$ & Violent behavior \\
\hline 7. & $\begin{array}{l}\text { Subu et al. } \\
(2016)\end{array}$ & 3 & Indonesia & $\begin{array}{l}\text { To know the impact of } \\
\text { stigma, in relation to } \\
\text { violent behavior toward } \\
\text { patients and know the } \\
\text { behavior of violence } \\
\text { committed by patients } \\
\text { toward others }\end{array}$ & $\begin{array}{l}\text { Constructivist } \\
\text { grounded theory }\end{array}$ & $\begin{array}{l}30 \text { participants } \\
\text { consisting of } \\
\text { schizophrenia } \\
\text { patients and } \\
\text { nurses }\end{array}$ & $\mathrm{n} / \mathrm{a}$ & $\begin{array}{l}\text { Family feels scared, } \\
\text { uncomfortable, and } \\
\text { feel isolated in the } \\
\text { community }\end{array}$ & Violent behavior \\
\hline 8. & $\begin{array}{l}\text { Astuti } \\
(2017)\end{array}$ & 2 & Indonesia & $\begin{array}{l}\text { To know the condition of } \\
\text { patient and family } \\
\text { during pasung, reason of } \\
\text { the family to-do pasung, } \\
\text { knowledge of severe } \\
\text { mental illness and the } \\
\text { recovery process of } \\
\text { family, and knowledge } \\
\text { and attitude of the } \\
\text { community toward } \\
\text { patient in pasung }\end{array}$ & $\begin{array}{l}\text { Convergent parallel } \\
\text { mixed methods }\end{array}$ & $\begin{array}{l}\text { Quantitative data } \\
\text { sources are } 10 \\
\text { families of patient } \\
\text { in pasung and } 3 \\
\text { families as } \\
\text { qualitative data } \\
\text { sources from } \\
\text { quantitative data } \\
\text { samples }\end{array}$ & $\mathrm{n} / \mathrm{a}$ & Stigma & $\begin{array}{l}\text { Lack of knowledge } \\
\text { (mental disorders and } \\
\text { how to care), violent } \\
\text { behavior, and families } \\
\text { cannot accompany } \\
\text { patient continuously }\end{array}$ \\
\hline 9. & $\begin{array}{l}\text { Yusuf et } \\
\text { al. (2017) }\end{array}$ & 3 & Indonesia & $\begin{array}{l}\text { To know family support } \\
\text { for post-pasung mental } \\
\text { patients }\end{array}$ & $\begin{array}{l}\text { Phenomenological } \\
\text { study }\end{array}$ & $\begin{array}{l}9 \text { family members } \\
\text { with post-pasung } \\
\text { patients }\end{array}$ & $\begin{array}{l}7 \text { days - } \\
24 \text { years }\end{array}$ & $\begin{array}{l}\text { Desire to protect } \\
\text { patient and keep } \\
\text { environment clean, } \\
\text { and family considers } \\
\text { pasung will cure the } \\
\text { patient }\end{array}$ & $\begin{array}{l}\text { Violent behavior, and } \\
\text { unable to care }\end{array}$ \\
\hline 10. & $\begin{array}{l}\text { Asher et } \\
\text { al. (2017) }\end{array}$ & 3 & Ethiopia & $\begin{array}{l}\text { To understand the } \\
\text { experiences, and reasons } \\
\text { for pasung in people } \\
\text { with schizophrenia in } \\
\text { the community }\end{array}$ & $\begin{array}{l}\text { Phenomenological } \\
\text { study }\end{array}$ & $\begin{array}{l}4 \text { schizophrenia } \\
\text { patients and } 17 \\
\text { families members } \\
\text { with } \\
\text { schizophrenia } \\
\text { patients }\end{array}$ & $\mathrm{n} / \mathrm{a}$ & $\begin{array}{l}\text { Family feel the } \\
\text { burden without the } \\
\text { support of others and } \\
\text { they feel hopeless and } \\
\text { helpless. }\end{array}$ & $\begin{array}{l}\text { Violent behavior } \\
\text { (physically or sexually) } \\
\text { and pasung makes } \\
\text { family easy to provide } \\
\text { treatment }\end{array}$ \\
\hline
\end{tabular}


Table 2. Summary of articles on systematic search results

\begin{tabular}{|c|c|c|c|c|c|c|c|c|c|}
\hline \multirow{2}{*}{\multicolumn{2}{|c|}{ Author (Year) }} & \multirow{2}{*}{$\begin{array}{l}\text { JBI } \\
\text { Lvl. }\end{array}$} & \multirow{2}{*}{ Country } & \multirow{2}{*}{ Objective } & \multirow{2}{*}{ Method } & \multirow{2}{*}{ Subject } & \multirow{2}{*}{$\begin{array}{l}\text { Duration } \\
\text { of } \\
\text { Pasung }\end{array}$} & \multicolumn{2}{|c|}{ Burden } \\
\hline & & & & & & & & Subjective & Objective \\
\hline \multicolumn{10}{|c|}{ Evidence of Effectiveness } \\
\hline 11. & $\begin{array}{l}\text { Laila et al. } \\
\text { (2018) }\end{array}$ & 3 & Indonesia & $\begin{array}{l}\text { To explore the } \\
\text { perceptions of family } \\
\text { members of } \\
\text { schizophrenia patients } \\
\text { and other key } \\
\text { stakeholders about } \\
\text { pasung }\end{array}$ & $\begin{array}{l}\text { Phenomenological } \\
\text { study }\end{array}$ & $\begin{array}{l}3 \text { family members } \\
\text { who do pasung } \\
\text { for patients with } \\
\text { schizophrenia }\end{array}$ & $\begin{array}{l}10 \text { days - } \\
3 \text { years }\end{array}$ & $\begin{array}{l}\text { Pasung due to } \\
\text { safety/protection for } \\
\text { patient, pasung is a } \\
\text { common practice in } \\
\text { the community, and } \\
\text { feel distrust of health } \\
\text { services (due to } \\
\text { relapse). }\end{array}$ & $\begin{array}{l}\text { Financial issue } \\
\text { (transportation in } \\
\text { medical treatment, basic } \\
\text { needs, and over-eating) }\end{array}$ \\
\hline 12. & $\begin{array}{l}\text { Buanasari } \\
\text { et al. } \\
(2018)\end{array}$ & 3 & Indonesia & $\begin{array}{l}\text { To explore the } \\
\text { experience of } \\
\text { adolescents having } \\
\text { parents with severe } \\
\text { mental disorders in } \\
\text { pasung }\end{array}$ & $\begin{array}{l}\text { Phenomenological } \\
\text { study }\end{array}$ & $\begin{array}{l}6 \text { participants } \\
\text { aged } 14-19 \text { years }\end{array}$ & $\mathrm{n} / \mathrm{a}$ & $\begin{array}{l}\text { Lose the figure of } \\
\text { parents, family feels } \\
\text { sadness, and pity }\end{array}$ & $\begin{array}{l}\text { Family become bread- } \\
\text { winners and pasung } \\
\text { makes it easy for family } \\
\text { to provide food, hygiene, } \\
\text { and elimination needs } \\
\end{array}$ \\
\hline 13. & $\begin{array}{l}\text { Yunita et } \\
\text { al. (2019) }\end{array}$ & 3 & Indonesia & $\begin{array}{l}\text { To determine the } \\
\text { appearance of families } \\
\text { taking care of patients } \\
\text { with mental disorders } \\
\text { post-pasung }\end{array}$ & $\begin{array}{l}\text { Phenomenological } \\
\text { study }\end{array}$ & $\begin{array}{l}6 \text { families with } \\
\text { patients with } \\
\text { mental disorders } \\
\text { post-pasung }\end{array}$ & $\begin{array}{l}3 \text { weeks - } \\
10 \text { years }\end{array}$ & $\begin{array}{l}\text { Family feel negative } \\
\text { feelings (tired and } \\
\text { helpless). }\end{array}$ & $\begin{array}{l}\text { Financial issue (run out } \\
\text { of money, lack of } \\
\text { knowledge, }\end{array}$ \\
\hline 14. & $\begin{array}{l}\text { Wulandari, } \\
\text { Daulima, } \\
\text { and } \\
\text { Wardani } \\
(2019)\end{array}$ & 3 & Indonesia & $\begin{array}{l}\text { To identify stigma } \\
\text { resistance as a recovery } \\
\text { process in patients with } \\
\text { mental disorders post- } \\
\text { pasung }\end{array}$ & $\begin{array}{l}\text { Phenomenological } \\
\text { study }\end{array}$ & $\begin{array}{l}12 \text { patients } \\
\text { mental disorders } \\
\text { post-pasung }\end{array}$ & $\mathrm{n} / \mathrm{a}$ & Stigma & \\
\hline 15. & $\begin{array}{l}\text { Hall et al. } \\
(2019)\end{array}$ & 3 & Indonesia & $\begin{array}{l}\text { To know the experience } \\
\text { of social inclusion and } \\
\text { exclusion of people with } \\
\text { mental illness and their } \\
\text { families }\end{array}$ & $\begin{array}{l}\text { Phenomenological } \\
\text { study }\end{array}$ & $\begin{array}{l}10 \text { families aged } \\
26-70 \text { years }\end{array}$ & $\mathrm{n} / \mathrm{a}$ & $\begin{array}{l}\text { Stigma from the } \\
\text { surrounding (causes } \\
\text { relapse) }\end{array}$ & Violent behavior \\
\hline
\end{tabular}


in the community. Besides, the community is expected to provide social support for this population during the COVID-I9 pandemic. In Indonesia, mental health is the right of all the people, following the mandate stated in the Law of the Republic of Indonesia No. 18 of 2014 concerning mental health.

\section{Acknowledgement}

We would like to thank ourselves and INJEC for publishing our manuscript.

\section{Conflict of Interest}

All the authors have no conflict of interest related to the study.

\section{REFERENCES}

Amagai, M., Takahashi, M., \& Amagai, F. (2016). Qualitative study of resilience of family caregivers for patients with schizophrenia in Japan. Mental Health in Family Medicine, I2(4), 307-3/2.

Andreasen, N.C., \& Black, D.W. (2006). Introductory textbook of psychiatry (4th ed.). Washington, DC: American Psychiatric Publishing, Inc.

Arun, R., Inbakamal, S., Tharyan, A., \& Premkumar, P.S. (20I8). Spousal caregiver burden and its relation with disability in schizophrenia. Indian J Psychol Med, 40, $22-$ 28. doi: 10.4I03/IJPSYM.IJPSYM_204_17

Asher, L., Fekadu, A., Teferra, S., De Silva, M., Pathare, S., \& Hanlon, C. (2017). "I cry every day and night, I have my son tied in chains": physical restraint of people with schizophrenia in community settings in Ethiopia. Globalization and Health, 13(14), I-|4. doi: |0.| |86/s |2992-0|7-0273-I

Astuti, M. (2017). Kondisi orang dengan gangguan jiwa pasung, keluarga dan masyarakat lingkungannya di Kabupaten 50 Kota. Sosio Konsepsia: Jurnal Penelitian dan Pengembangan Kesejahteraan Sosial, 6(3), 256-268. doi: 10.33007/ska.v6i3.1000

Bhat, B.A., Khan, S., Manzoor, S., Niyaz, A., Tak, H.J., Anees, S-U.M., . . A Ahmad, I. (2020). A study on impact of COVID-19 lockdown on psychological health, economy and social life of people in
Kashmir. International Journal of Science and Healthcare Research, 5(2), 36-46.

Buanasari, A., Daulima, N.H.C., \& Wardani, I.Y. (20I8). The experience of adolescents having mentally ill parents with pasung. Enfermería Clínica, 28(Supl I Part A), 8387. doi: I0.1016/SII30-862I(I8)30043-3

Daulima, N.H.C., Rasmawati, \& Wardani, I.Y. (2019). Penurunan kemampuan kepala keluarga dalam memenuhi kebutuhan ekonomi keluarga: Studi fenomenologi pengalaman orang dengan gangguan jiwa paska pasung. Jurnal Keperawatan Indonesia, 22(2), 139-I46. doi: 10.7454/jki.v22i2.873

Dewi, A.R., Daulima, N.H.C., \& Wardani, I.Y. (2019). Managing family burden through combined family psychoeducation and care decision without pasung therapies. Enfermería Clínica, 29(52), 76-80. doi: I0.1016/j.enfcli.2019.04.012

Druss, B.G. (2020). Addressing the COVID-19 pandemic in populations with serious mental illness. JAMA Psychiatry. doi: 10.1001/jamapsychiatry.2020.0894

Firdaus. (2016). Pemenuhan Hak Atas Kesehatan Bagi Penyandang Skizofrenia di Daerah Istimewa Yogyakarta. Jurnal Ilmiah Kebijakan Hukum, 10(I), 87-103. doi: I0.3064I/kebijakan.20 I6.VI0.87-I03

Greene, J., Cohen, D., Siskowski, C., \& Toyinbo, P. (2017). The relationship between family caregiving and the mental health of emerging young adult caregivers. The Journal of Behavioral Health Services \& Research, 44(4), 55I-563. doi: |0.|007/s | |4|4-0|6-9526-7

Gugus Tugas Percepatan Penanganan COVID19. (2020). Data Sebaran. Retrieved I July, 2020, from https://covid I9.go.id/

Hall, T., Kakuma, R., Palmer, L., Minas, H., Martins, J., \& Kermode, M. (2019). Social inclusion and exclusion of people with mental illness in Timor-Leste: a qualitative investigation with multiple stakeholders. BMC Public Health, 19:702. doi: |0.1 |86/s | 2889-019-7042-4

Hamada, K., \& Fan, X. (2020). The impact of COVID-19 on individuals living with serious mental illness. Schizophrenia Research, $\quad x x x(x x x)$ doi: 10.1016/j.schres.2020.05.054

Hartini, N., Fardana, N.A., Ariana, A.D., \& Wardana, N.D. (20I8). Stigma toward people with mental health problems in 
Indonesia. Psychology Research and Behavior

Management, II, 535-54I. doi: 10.2I47/PRBM.SI7525I

Holmes, E. A., O'Connor, R., Perry, V., Tracey, I., Wessely, S., Arseneault, L., . . . Bullmore, E. (2020). Multidisciplinary research priorities for the COVID-19 pandemic: A call for action for mental health science. Lancet Psychiatry, 7, 547560. doi: $10.1016 / S 2215-0366(20) 30168-1$

Huang, H.M., Jen, Y.C., \& Lien, Y.F. (2016). Stigma experienced by caregivers of patients with schizophrenia: A qualitative study. International Journal of Nursing \& Clinical Practices, 3, 182 . doi: I0.15344/2394-4978/2016//82

Keliat, B.A., Marliana, T., Windarwati, H.D., Mubin, M.F., Sodikin, M.A., Kristianingsih, T., . . . Kembaren, L. (2020). Dukungan Kesehatan Jiwa dan psikososial (Mental health and psychosocial support) COVID-19: Keperawatan jiwa (I $\left.\right|^{\text {st }}$ ed.). Depok: FIK-UI.

Koujalgi, S.R., \& Patil, S.R. (20/3). Family burden in patient with schizophrenia and depressive disorder: A comparative study. Indian J Psychol Med, 35:25I. doi: 10.4103/0253-7I76.119475

Laila, N.H., Mahkota, R., Krianto, T., \& Shivalli, S. (2018). Preception about pasung (physical restraint and confinement) of schizophrenia patients: A qualitative study among family members and other key stakeholders in Bogor Regency, West Java Province, Indonesia 2017. International Journal of Mental Health System, I2(35), I7. doi: I0.1 I86/s |3033-018-02/6-0

Laila, N.H., Mahkota, R., Shivalli, S., Bantas, K., \& Krianto, T. (20/9). Factors associated with pasung (physical restraint and confinement) of schizophrenia patients in Bogor regency, West Java Province, Indonesia 2017. BMC Psychiatry, 19(162), I-8. doi: |0.| |86/s | 2888-0|9-2।38-z

Madathumkovilakath, N.B., Kizhakkeppattu, S., Thekekunnath, S., \& Kazhungil, F. (20I8). Coping strategies of caregivers towards aggressive behaviors of persons with severe mental illness. Asian Journal of Psychiatry, 35, 29-33. doi: 10.1016/j.ajp.2018.04.032

Mantovani, L.M., Ferretjans, R., Marçal, I.M., Oliveira, A.M., Guimarães, F.C., \& Salgado, J.V. (2016). Family burden in schizophrenia: The influence of age of onset and negative symptoms. Trends Psychiatry Psychother, 38(2), 96-99. doi: 10.1590/2237-6089-2015-0082

Menteri Kesehatan Republik Indonesia. (2017). Peraturan Menteri Kesehatan Republik Indonesia No. 54 tahun 2017 tentang Penanggulangan pemasungan pada orang dengan gangguan jiwa. Jakarta: Kementerian Kesehatan Republik Indonesia.

Nihayati, H.E., Mukhalladah, D.A., \& Krisnana, I. (20I6). Pengalaman keluarga merawat klien gangguan jiwa pasca pasung. Jurnal Ners, I/(2), 283-287. doi: I0.20473/jn.v I Ii 2.2988

Nurhayati, N.P., Widjanarko, B., \& Nugraheni, S.A. (2020). Determinant factors that influence in the installation of people with the soul disorders in the Brebes District (Study of family members who have mental illness pasung). The International Journal of Health, Education and Social (IJHES), 3(5), I I I6.

Puteh, I., Marthoenis, M., \& Minas, H. (20II). Aceh Free Pasung: Releasing the mentally ill from physical restraint. Imternational Journal of Mental Health Systems, 5(10), I5. doi: 10.1 I86/I752-4458-5-10

Repišti, S., Jovanović, N., Kuzman, M.R., Medved, S., Jerotić, S., Ribić, E., . . . Russo, M. (2020). How to measure the impact of the COVID-1 9 pandemic on quality of life: COVI9-QoL - the development, reliability and validity of a new scale. Global Psychiatry, 3(2), I-I0. doi: 10.2478/gP2020-0016

Sharma, R., Sharma, S.C., \& Pradhan, S.N. (2017). Assessing caregiver burden in caregivers of patients with schizophrenia and bipolar affective disorder in Kathmandu Medical College. I Nepal Health Res Counc, 15(37), 258-263. doi: I0.3126/jnhrc.v15i3.1885 I

Shrestha, Y. (2018). Knowledge and attitude of family member of mentally ill patient regarding restraint, 2016. Archives of Psychiatric Nursing, 32, 297-299. doi: 10.1016/j.apnu.2017.11.018

Souza, A.L.R., Guimarães, R.A., Vilela, D.D.A., Assis, R.M.D, Oliveira, L.M.D.A.C., Souza, M.R., . . . Barbosa, M.A. (20|7). Factors associated with the burden of family caregivers of patients with mental disorders: a cross-sectional study. BMC 
Psychiatry, 17(353), I-I0. doi: |0.| |86/s | 2888-0|7-|50|-I

Subu, M.A., Holmes, D., \& Elliot, J. (2016). Stigmatisasi dan perilaku kekerasan pada orang dengan gangguan jiwa (ODGJ) di Indonesia. Jurnal Keperawatan Indonesia, 19(3), I9I-199. doi: 10.7454/jki.v19i3.48।

Torales, J., O'Higgins, M., Castaldelli-Maia, J.M., \& Ventriglio, A. (2020). The outbreak of COVID-19 coronavirus and its impact on global mental health. International Journal of Social Psychiatry, 00(0), I-4. doi: DOI: I0.1 177/00207640209152/2

Venkatesh, B.T., Andrews, T., Parsekar, S.S., Singh, M.M., \& Menon, N. (20I5). Stigma and mental health-caregivers' perspective: A qualitative analysis. Clinical Epidemiology and Global Health, 4, 23-27. doi: 10.1016/j.cegh.2015.06.003

WHO. (2018). Schizophrenia. Retrieved 30 September, 2019, from https://www.who.int/news-room/factsheets/detail/schizophrenia

WHO. (2020). Catatan tentang aspek kesehatan jiwa dan psikososial wabah COVID-19 Versi I.0. Retrieved 2I June, 2020, from https://www.who.int/docs/defaultsource/searo/indonesia/covid I 9/catatantentang-aspek-kesehatan-jiwa-danpsikososial-wabah-covid-19-feb-2020indonesian.pdf?sfvrsn=ebae5645_2

Wulandari, I.A.P., Daulima, N.H.C., \& Wardani, I.Y. (2019). The fight against stigma in the recovery process of post-pasung mentally ill patients. Enfermería Clínica, 29(S2), 295299. doi: 10.1016/j.enfcli.2019.04.037

Yu, Y., Liu, Z-w., Tang, B-w., Zhao, M., Liu, Xg., \& Xiao, S-y. (2017). Reported family burden of schizophrenia patients in rural China. PLOS ONE, 12(6). doi: I0.137I/journal.pone.0179425

Yunita, F.C., Yusuf, A., Nihayati, H.E., \& Hilfida, N.H. (2019). Coping strategies used by families in Indonesia when caring for patients with mental disorders postpasung, based on a case study approach. General Psychiatry, 33:el00035. doi: I0.1 I36/gpsych-2018-100035

Yusuf, A., Tristiana, R.D., \& Purwo, I. (20I7). Fenomena pasung dan dukungan keluarga terhadap pasien gangguan jiwa pasca pasung. Jurnal Keperawatan Padjajaran, 5(3), 302-3।4. doi: 10.24198/jkp.v5i3.653 